\title{
Increase of Viability of Entrapped Cells of Lactobacillus delbrueckii ssp. bulgaricus in Artificial Sesame Oil Emulsions
}

\author{
R. C. W. Hou, ${ }^{*}$ M. Y. Lin, $†$ M. M. C. Wang, ${ }^{\star}$ and J. T. C. Tzen* \\ *Graduate Institute of Biotechnology and \\ †Department of Food Science, \\ National Chung-Hsing University, \\ Taichung, Taiwan 40227 ROC
}

\section{ABSTRACT}

A technique was developed to protect lactic acid bacteria (Lactobacillus delbrueckii ssp. bulgaricus) against simulated gastrointestinal conditions by encapsulation of bacterial cells within artificial sesame oil emulsions. Purified sesame oil bodies consisting of approximately 99\% oil, $0.5 \%$ phospholipid, and $0.5 \%$ protein were decomposed by heating at $70^{\circ} \mathrm{C}$ for $1 \mathrm{~h}$. The bacteria cultured in nonfat milk were encapsulated in artificial oil emulsions constituted with decomposed sesame oil bodies and excess sesame or vegetable cooking oil. Viability of bacteria in storage at $4^{\circ} \mathrm{C}$ for $16 \mathrm{~d}$ was substantially elevated from 0.023 to $5.45 \%$ after encapsulation. Compared with free cells, the entrapped bacteria demonstrated a significant increase (approximately $10^{4}$ times) in survival rate when subjected to simulated high acid gastric or bile salt conditions. The results indicate that artificial sesame oil emulsion may serve as an effective biocapsule for encapsulation of bacteria in dairy products.

(Key words: biocapsule, encapsulation, lactic acid bacterium, sesame oil emulsion)

Abbreviation key: GIT = gastrointestinal tract, LAB = lactic acid bacteria, MRS = deMann Rogosa and Sharpe, $\mathbf{N D M}=$ nonfat dry milk.

\section{INTRODUCTION}

Lactic acid bacteria (LAB) are among the most important probiotic microorganisms typically associated with the human gastrointestinal tract (GIT). Nearly a century ago, the longevity of Caucasians was attributed to their consumption of large quantities of fermented milk containing lactobacilli (Metchnikoff, 1908). Over

Received July 5, 2002.

Accepted August 28, 2002.

Corresponding author: J. T. C. Tzen; e-mail address: TCTZEN@ dragon.nchu.edu.tw. the last $20 \mathrm{yr}$, numerous health and nutritional benefits have been ascribed to probiotics such as lactic acid bacteria. These include immune stimulation, cholesterol reduction, inhibition of pathogen growth, maintenance of a healthy gut microflora, prevention of cancer, improvement in lactose utilization, prevention of diarrhoeal diseases or constipation, absorption of calcium, and synthesis of vitamins and predigestion of proteins (De Simone et al., 1991; Havenaar and Huis in't Veld, 1992; Fuller, 1993; Sanders, 1993; lee and Salminen, 1995; Tannock, 1995; Jankowski, et al., 1997).

Currently, probiotics have been supplemented to diverse food products to create "functional foods or nutraceuticals" in global markets (Stanton et al., 2001). Viability and functional activity of probiotics are major concerns in these supplements, as a sufficient number of bacteria must resist the gastric juice and bile salts in the GIT before reaching the colon. To provide functional properties, the minimum level of viable bacteria is approximately $10^{6} \mathrm{cfu} / \mathrm{ml}$ of product at the expiry date, and the suggested therapeutic dose is $10^{8}-10^{9}$ viable cells per day (Kurmann and Rasic, 1991). However, studies indicate that probiotics may not survive in sufficient number and retain their activity in market preparations or in the host GIT (Hamilton-Miller et al., 1999). A number of approaches are being explored to increase viability of probiotic bacteria in commercial and experimented products, including selection of acid and bile resistant strains, use of oxygen impermeable containers, microencapsulation, two-step fermentation, stress adaptation, and incorporation of micronutrients such as peptides and amino acids (Shah, 2000).

Sesame oil has long been used for human consumption in Asian countries. The oil is confined to intracellular organelles called oil bodies in sesame seed (Peng and Tzen, 1998). An oil body of sesame seed is approximately $2 \mu \mathrm{m}$ in diameter and contains a triacylglycerol matrix surrounded by a monolayer of phospholipids and an abundant structural protein, oleosin (Chen et al., 1998). Sesame oil bodies consist of approximately $99 \%$ oil (mainly triacylglycerol), $0.5 \%$ phospholipid, and 

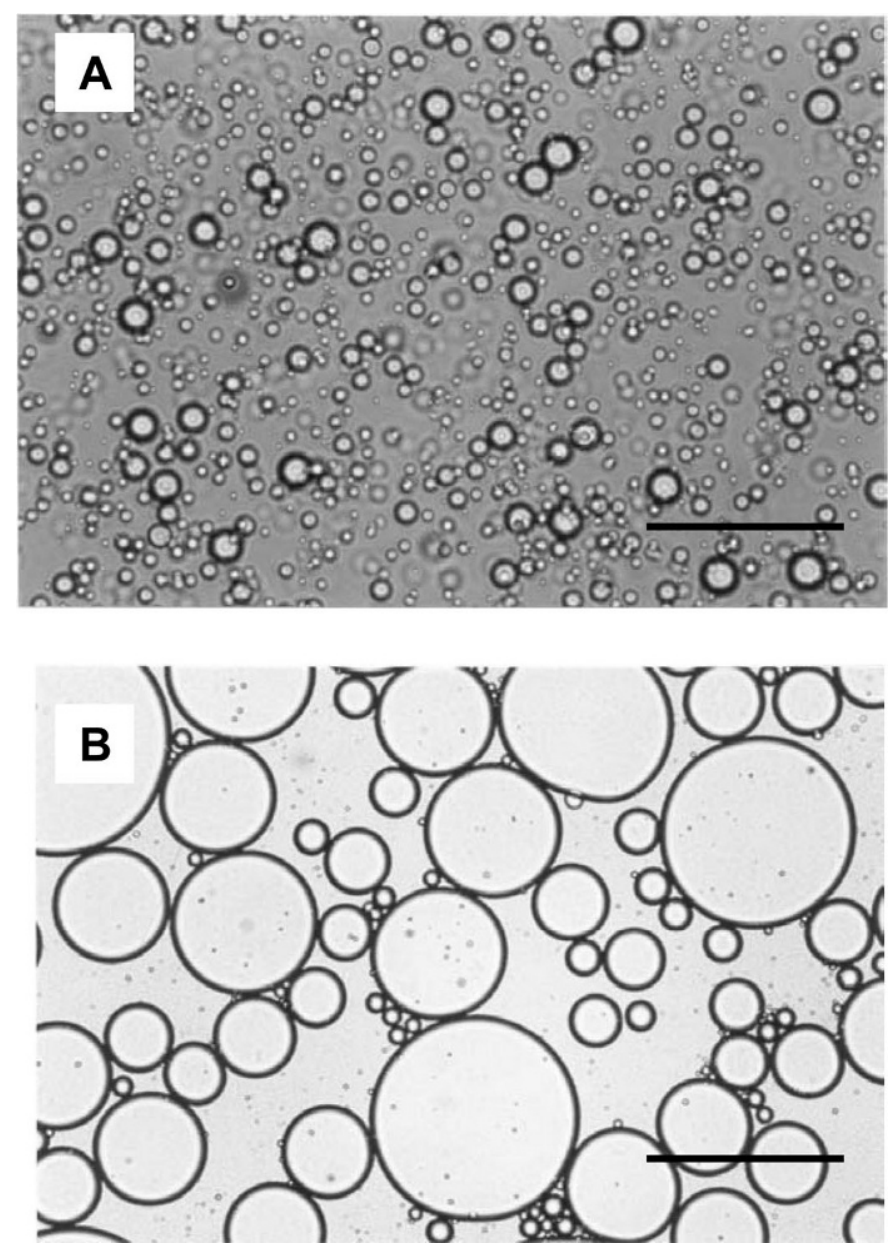

Figure 1. Light microscopy of native sesame oil bodies (A) and enlarged artificial sesame oil emulsions (B). Bar represents $10 \mu \mathrm{m}$ (A) or $100 \mu \mathrm{m}$ (B).

0.5\% protein (Tzen et al., 1993). Oil bodies are remarkably stable both in the cell and in isolated preparation as a consequence of the steric hindrance and electronegative repulsion provided by oleosins on their surfaces (Tzen et al., 1992); and it has been suggested that the entire surface of an oil body is covered by oleosins (Tzen and Huang, 1992). Therefore, these abundant and compressed oil bodies in the cells of a mature seed never coalesce or aggregate. Technically, stable artificial oil bodies can be reconstituted with triacylglycerol, phospholipid, and oleosin via sonication (Tzen et al., 1998).

To date, encapsulation methods have been widely applied to enhance viability of probiotic bacteria in commercial products. Several studies have shown successful microencapsulation and coating of bacteria using various encapsulating materials and methods (Jankowski et al., 1997; Kebary et al., 1998; Khalil and Mansour, 1998; Lee and Heo, 2000; Sultana, et al., 2000). In light of the oil quality and structural integrity of sesame oil

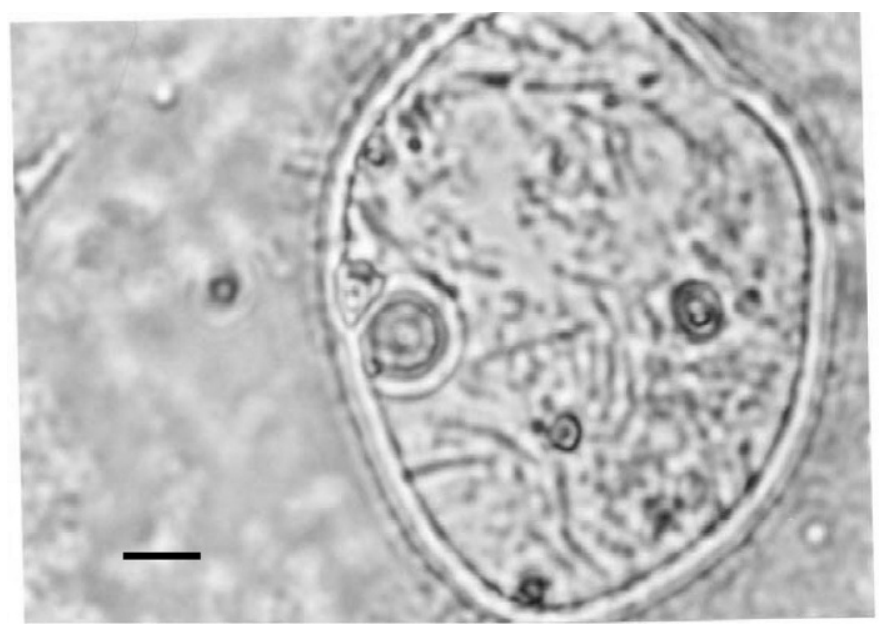

Figure 2. Light microscopy of lactic acid bacteria (Lactobacillus delbrueckii ssp. bulgaricus) encapsulated within artificial sesame oil bodies. Bar represents $10 \mu \mathrm{m}$.

bodies, we speculate that artificial sesame oil emulsion may serve as a suitable wrapper to encapsulate and protect probiotic bacteria in human GIT. To explore this possibility, lactic acid bacteria were encapsulated with artificial sesame oil emulsions of various compositions and subjected to viability test under simulated gastrointestinal conditions. The results suggest that artificial sesame oil emulsion is a potential biocapsule to encapsulate bacteria for commercial utilization in dairy products.

\section{MATERIALS AND METHODS}

\section{Bacteria and Media}

Lactic acid bacterium, Lactobacillus delbrueckii ssp. bulgaricus was transferred twice in lactobacilli MRS (deMann Rogosa and Sharpe) broth (Difco, Detroit, MI) at $37^{\circ} \mathrm{C}$. Cultures were collected from MRS broth and reconstituted nonfat dry milk (NDM) after $14 \mathrm{~h}$. For long term storage, the original culture was diluted 1/2 with $10 \%$ reconstituted NDM and dispensed into sterile 1.5-ml Eppendorf tubes for storage at $-80^{\circ} \mathrm{C}$.

\section{Preparation of Sesame Oil Bodies and Examination of their Stability under Various Temperature Conditions}

Mature seeds of sesame (Sesamum indicum L., Tainan1) were a gift from the Crop Improvement Department, Tainan District Agricultural Improvement Station. Oil bodies were extracted from mature sesame seeds according to the procedure reported by Tzen et al. (1997). Stability of the purified oil bodies was observed 
Table 1. Viability of encapsulated and free lactic acid bacteria (LAB) during storage in nonfat milk at $4^{\circ} \mathrm{C}$.

\begin{tabular}{lllllll}
\hline & \multicolumn{5}{c}{ Viability (cfu/ml) } \\
\cline { 2 - 6 } Storage days & 0 & 3 & 7 & 10 & 14 & 16 \\
\hline Encapsulated LAB & $2.2 \pm 5.1 \times 10^{8}$ & $1.1 \pm 1.5 \times 10^{8}$ & $1.8 \pm 2.0 \times 10^{8}$ & $9.7 \pm 3.3 \times 10^{7}$ & $6.1 \pm 3.0 \times 10^{7}$ & $1.2 \pm 4.0 \times 10^{7}$ \\
Free LAB & $2.6 \pm 2.0 \times 10^{8}$ & $4.0 \pm 1.0 \times 10^{6}$ & $8.6 \pm 2.1 \times 10^{5}$ & $1.6 \pm 2.7 \times 10^{5}$ & $5.4 \pm 0.7 \times 10^{4}$ & $6.0 \pm 2.1 \times 10^{4}$ \\
\hline
\end{tabular}

Each value in the table is the mean \pm SD of three trials.

under a Nikon type 104 light microscope after incubation in a water bath at $40,50,55,60,70,80,90$, or $100^{\circ} \mathrm{C}$ for $1 \mathrm{~h}$.

\section{Encapsulation of LAB with Artificial Oil Emulsions}

Decomposed sesame oil bodies at $70^{\circ} \mathrm{C}$ were selected to reconstitute artificial oil emulsions for encapsulation of LAB. The decomposed oil bodies (approximately 50 $\mu \mathrm{l})$ were first cooled to $40^{\circ} \mathrm{C}$ and then mixed with 10 , 25,50 , or 100 times (by volume) commercial sesame oil or vegetable cooking oil (purchased from a local supermarket) containing LAB cultured in $10 \%$ nonfat milk. The mixture was gently vortexed for $15 \mathrm{~min}$ to facilitate encapsulation of bacteria in reconstituted oil emulsions. Encapsulation was also examined under the light microscope. The resulting cultures were stored at $4^{\circ} \mathrm{C}$ before use.

\section{Viability of Bacteria in Storage at $4^{\circ} \mathrm{C}$}

The encapsulated and free bacterial cells were stored at $4^{\circ} \mathrm{C}$ in a refrigerator, and sampling $(5 \mathrm{ml}$ for each bacterial culture) was made at 3- or 4-d intervals for $16 \mathrm{~d}$. The samples were mixed individually with 10$\mathrm{ml}$ sterile reconstituted NDM in test tubes, and then subjected to survival cell count. For each sample, an aliquot of $100 \mu \mathrm{l}$ was diluted $1 / 10$ and then serially diluted to obtain a sensible dilution for plating. Cell counts, performed in triplicate, were calculated from the colonies on lactobacilli MRS agar plates after $48 \mathrm{~h}$ incubation at $37^{\circ} \mathrm{C}$ under anaerobic conditions, and thus expressed as colony-forming units per $\mathrm{ml}(\mathrm{cfu} / \mathrm{ml})$.

\section{Viability of Bacteria in Simulated High-Acid Gastric Conditions}

The encapsulated and free bacteria were separately added with MRS broth that had been adjusted to $\mathrm{pH}$ $1.5,2.0$, or 3.5 , and incubated at $37^{\circ} \mathrm{C}$. Samples were taken hourly for $4 \mathrm{~h}$, and survival cell counts were determined by plating as described previously.

\section{Viability of Bacteria in Simulated Bile Salt Condition}

The encapsulated and free bacteria were cultured in MRS broth adjusted to $\mathrm{pH} 5.5$ and supplemented with filter-sterilized porcine bile extract (Sigma) at a final concentration of $1.2 \%$. The samples were incubated at $37^{\circ} \mathrm{C}$ for $3 \mathrm{~h}$. Aliquots of $100 \mu \mathrm{l}$ were taken at the end of each hour to determine the survival cell count by plating as described previously.

\section{RESULTS AND DISCUSSION}

\section{Reconstitution of Artificial Sesame Oil Emulsions}

The present attempt to develop a novel encapsulation technique to enhance bacterial viability in storage and in gastrointestinal conditions is based on our current knowledge on the characteristics of seed oil body organization (Lin et al., 2002). Because the dimensions of native sesame spherical oil bodies $(\sim 2 \mu$ m in diameter) and the LAB $(\sim 10 \mu \mathrm{m}$ in length) are incompatible, reconstitution of larger artificial oil emulsions becomes necessary. The reconstitution involves disintegrating the native oil bodies and subsequent reconstituting

Table 2. Viability of encapsulated and free lactic acid bacteria (LAB) in low pH MRS broth.

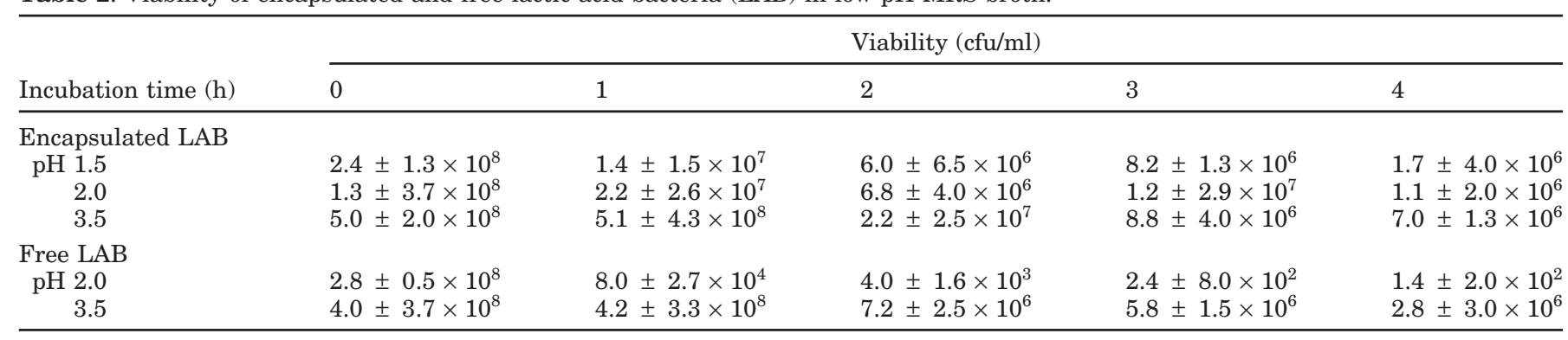

Each value in the table is the mean $\pm \mathrm{SD}$ of three trials. 
Table 3. Viability of encapsulated and free lactic acid bacteria (LAB) in $1.2 \%$ bile salt.

\begin{tabular}{lllll}
\hline & \multicolumn{4}{c}{ Viability $(\mathrm{cfu} / \mathrm{ml})$} \\
\cline { 2 - 5 } Incubation time $(\mathrm{h})$ & 0 & 1 & 2 & 3 \\
\hline Encapsulated LAB & $2.2 \pm 5.1 \times 10^{8}$ & $8.0 \pm 3.1 \times 10^{6}$ & $2.4 \pm 1.5 \times 10^{6}$ & $2.6 \pm 3.7 \times 10^{6}$ \\
Free LAB & $2.6 \pm 2.1 \times 10^{8}$ & $6.0 \pm 1.9 \times 10^{4}$ & $2.0 \pm 3.7 \times 10^{3}$ & $9.3 \pm 2.4 \times 10^{1}$ \\
\hline
\end{tabular}

Each value in the table is the mean \pm SD of three trials.

with excess matrix oil. Purified sesame oil bodies were first subjected to heating at different temperature conditions for $1 \mathrm{~h}$. While the oil bodies remained intact at temperatures $<40^{\circ} \mathrm{C}$ and became slightly unstable at $50^{\circ} \mathrm{C}$, they apparently started to disintegrate at $60^{\circ} \mathrm{C}$ and largely decomposed at $70^{\circ} \mathrm{C}$ (data not shown). Complete disruption of the oil bodies occurred at temperatures $>90^{\circ} \mathrm{C}$. However, the disrupted components of these oil bodies heated at temperatures $>90^{\circ} \mathrm{C}$ could not be used for subsequent reconstitution, probably due to severe denaturation of proteins in these oil-storage organelles. Further work reveals that enlarged stable artificial oil emulsions could be reconstituted using sesame oil bodies decomposed at $70^{\circ} \mathrm{C}$ supplemented with 50 times (by volume) sesame or vegetable cooking oil (Figure 1).

\section{Encapsulation of LAB with Artificial Sesame Oil Emulsions}

Successful encapsulation of LAB was achieved when bacteria cultured in $10 \%$ reconstituted NDM were extensively mixed with excess sesame or vegetable cooking oil before reconstitution with the decomposed sesame oil bodies pretreated at $70^{\circ} \mathrm{C}$ for $1 \mathrm{~h}$. The size and morphology of artificial sesame oil emulsions containing $\mathrm{LAB}$ were dependent on the formulation compositions and processing conditions. In our optimal condition, spherical oil emulsions of approximately 20 to 200 $\mu \mathrm{m}$ in diameter (Figure 1B) were assembled with $50 \mu \mathrm{l}$ of decomposed sesame oil bodies and $2.5 \mathrm{ml}$ (50 times) of cooking oil containing milk-cultured bacteria. In this encapsulation, sufficient bacteria were entrapped within artificial oil emulsions as observed in light microscopy (Figure 2), and it appears that the LAB were randomly distributed in the oil matrix.

Though artificial oil emulsions were found to be reconstituted in better efficiency and stronger integrity via sonication (Tzen et al., 1998), LAB are too fragile to endure such treatment. In our experimental conditions, though stable artificial oil emulsions were formed by sonication, no viable bacteria were observed thereafter (data not shown).

\section{Survival Rate of Encapsulated and Free LAB in Storage at $4^{\circ} \mathrm{C}$}

The survival rate of encapsulated and free $\mathrm{LAB}$ stored in nonfat milk at $4^{\circ} \mathrm{C}$ is shown in Table 1 . The viable cell count of encapsulated bacteria dropped from $2.2 \times 10^{8}$ to $1.2 \times 10^{7} \mathrm{cfu} / \mathrm{ml}$, whereas that of free cells dropped from $2.6 \times 10^{8}$ to $6.0 \times 10^{4} \mathrm{cfu} / \mathrm{ml}$ over a storage period of $16 \mathrm{~d}$. Evidently, viability of LAB was considerably increased, from 0.023 to $5.45 \%$ (more than 200 times), by encapsulation of bacteria within artificial oil emulsions.

\section{Survival Rate of Encapsulated and Free LAB in Simulated High-Acid Gastric or Bile Salt Conditions}

To evaluate the potential utilization of artificial oil emulsions in bacterial protection against gastrointestinal environments, encapsulated and free LAB were separately exposed to in vitro simulated GIT conditions including high-acid gastric and bile salt conditions. No significant difference of bacterial viability between the encapsulated and free cells was detected when they were cultured at $\mathrm{pH} 3.5$ (Table 2) or higher $\mathrm{pH}$ conditions (data not shown). The viability of free LAB was significantly reduced in the culture solution at $\mathrm{pH} 2.0$, compared with that at $\mathrm{pH} 3.5$ (Table 2). This significant reduction of bacterial viability at $\mathrm{pH} \leq 2.0$ could be reversed when the LAB were encapsulated in artificial sesame oil emulsions. This observation shows that, after encapsulation, the survival rate of $\mathrm{LAB}$ at $\mathrm{pH} 2.0$ was elevated by approximately $10^{4}$ times.

The viability of free LAB was drastically reduced within $3 \mathrm{~h}$ when cultured at $\mathrm{pH} 5.5$ in the presence of $1.2 \%$ bile extract (Table 3 ). This drastic reduction of bacterial viability in the presence of bile salt could be rescued to a level similar to that in the absence of bile salts when the LAB were encapsulated in artificial sesame oil emulsions. Apparently, the survival rate of LAB in the presence of bile salts was also elevated by approximately $10^{4}$ times after encapsulation. Taken together, encapsulation with artificial sesame oil emulsions exerts a significant protective effect on LAB in simulated high acid gastric and bile salt conditions. It is thus concluded that artificial sesame oil emulsion may serve 
as a suitable biocapsule to encapsulate bacteria for commercial utilization in dairy products.

\section{ACKNOWLEDGMENTS}

The authors thank Professor Chih-Ning Sun for critical reading of the manuscript and Dr. Tien-Joung Yiu of the Crop Improvement Department, Tainan District Agricultural Improvement Station for supplying sesame seeds.

\section{REFERENCES}

Chen, E. C. F., S. S. K. Tai, C. C. Peng, and J. T. C. Tzen. 1998. Identification of three novel unique proteins in seed oil bodies of sesame. Plant Cell Physiol. 39:935-941.

De Simone, C., E. Rosati, S. Moretti, B. Salvadori, R. Vesely, and E. Jirillo. 1991. Probiotics and stimulation of the immune response. Eur. J. Clin. Nutr. 45:32-34.

Fuller, R. 1993. Probiotic foods: Current use and future developments. Int. Food Ingred. 3:23-26.

Hamilton-Miller, J. M. T., S. Shah, and J. T. Winkler. 1999. Public health issues arising from microbiological and labeling quality of foods and supplements containing probiotic microorganisms. Public Health Nutr. 2:223-229.

Havenaar, R., and J. H. J. Huis in't Veld. 1992. Probiotics: a general view. The lactic acid bacteria. In: Wood, B. J. B. ed. The lactic acid bacteria in health and disease. London: Elsevier Applied Science 1:151-171.

Jankowski, T., M. Zielinska, and A. Wysakowska. 1997. Encapsulation of lactic acid bacteria with alginate/starch capsules. Biotechnol. Tech. 11:31-34.

Kebary, K. M. K., S. A. Hussein, and R. M. Badawi. 1998. Improving viability of bifidobacterium and their effect on frozen ice milk. Egyptian J. Dairy Sci. 26:319-337.

Khalil, A. H., and E. H. Mansour. 1998. Alginate encapsulated bifidobacteria survival in mayonnaise. J. Food Sci. 63:702-705.

Kurmann, J. A., and J. L. Rasic. 1991. The health potential of products containing bifidobacteria. In: Robinson, R. K. ed. Therapeutic properties of fermented milks. London: Elsevier Science Publishers, Ltd. 117-158.

Lee, Y. K., and S. Salminen. 1995. The coming of age of probiotics. Trends Food Sci. Technol. 6:241-245.
Lee, K. Y., and T. R. Heo. 2000. Survival of Bifidobacterium longum immobilized in calcium alginate beads in simulated gastric juices and bile salt solution. Appl. Environ. Microbiol. 66:869-873.

Lin, L. J., S. S. K. Tai, C. C. Peng, and J. T. C. Tzen. 2002. Steroleosin, a sterol-binding dehydrogenase in seed oil bodies. Plant Physiol. 128:1200-1211.

Metchnikoff, E. 1908. The prolongation of life: optimistic studies. London: Heinemann.

Peng, C. C., and J. T. C. Tzen. 1998. Analysis of the three essential constituents of oil bodies in developing sesame seeds. Plant Cell Physiol. 39:35-42.

Salminen, S., E. Isolauri, and E. Salminen. 1996. Clinical uses of probiotics for stabilizing the gut mucosal barrier: successful strains and future challenges. Antonie Van Leeuwenhoek 70:347-358.

Sanders, M. E. 1993. Summary of conclusions from a consensus panel of experts on health attributes of lactic cultures: significance to fluid milk products containing cultures. J. Dairy Sci. 76:1819 1828 .

Shah, N. P. 2000. Probiotic Bacteria: Selective and enumeration and survival in dairy foods. J. Dairy Sci. 83:894-907.

Stanton, C., G. Gardiner, H. Meehan, K. Collins, G. Fitzgerald, P. B. Lynch, and R. P. Ross. 2001. Market potential for probiotics. Am. J. Clin. Nutr. 73(Suppl.):476S-483S.

Sultana, K., G. Godward, N. Reynolds, R. Arumugaswamy, P. Peiris, and K. Kailasapathy. 2000. Encapsulation of probiotic bacteria with alginate-starch and evaluation of survival in simulated gastrointestinal conditions and in yogurt. Int. J. Food Microbiol. 62:47-55.

Tannock, G. W. 1995. Role of probiotics. In Human Colonic Bacteria: Role in Nutrition, Physiology, and Pathology, eds. G. R. Gibson and G. T. Macfarlane. CRC Press, Boca Raton, Florida. 257-271.

Tzen, J. T. C., G. C. Lie, and A. H. C. Huang. 1992. Characterization of the charged components and their topology on the surface of plant seed oil bodies. J. Biol. Chem. 267:15626-15634.

Tzen, J. T. C. and A. H. C. Huang. 1992. Surface structure and properties of plant seed oil bodies. J. Cell Biol. 117:327-335.

Tzen, J. T. C., Y. Z. Cao, P. Laurent, C. Ratnayake, and A. H. C. Huang. 1993. Lipids, proteins, and structure of seed oil bodies from diverse species. Plant Physiol. 101:267-276.

Tzen, J. T. C., C. C. Peng, D. J. Cheng, E. C. F. Chen, and J. M. H. Chiu. 1997. A new method for seed oil body purification and examination of oil body integrity following germination. J. Biochem. 121:762-768.

Tzen, J. T. C., R. T. C. Chuang, J. C. F. Chen, and L. S. H. Wu. 1998 Coexistence of both oleosin isoforms on the surface of seed oil bodies and their individual stabilization to the organelles. J. Biochem. 123:319-324. 